\title{
Depositional Environment of the Sangkarewang Oil Shale, Ombilin Basin, Indonesia
}

\author{
Komang Anggayana ${ }^{1}$, Agus Haris Widayat ${ }^{1 *}$ \& Sri Widodo ${ }^{2}$ \\ ${ }^{1}$ Research Group of Earth Resources Exploration, \\ Faculty of Mining and Petroleum Engineering, Institut Teknologi Bandung, \\ Jalan Ganesha 10, Bandung, 40132, Indonesia \\ ${ }^{2}$ Mining Engineering Department, Hasanuddin University, \\ Jalan Perintis Kemerdekaan Km. 10, Tamalanrea, Makassar, 90245, Indonesia \\ *Email: haris@daad-alumni.de
}

\begin{abstract}
Five samples from a $56 \mathrm{~m}$ long drill core that was recovered from the lacustrine Sangkarewang oil shale have been studied by means of petrography and organic geochemistry in order to investigate the organic matter composition and depositional environment of the shale. The organic matter consisted of abundant lamalginite $(30 \%, \mathrm{v} / \mathrm{v})$ and a very limited amount of vitrinite, suggesting an aquatic depositional environment with minor terrestrial influence. Organic geochemical analysis exhibited the dominance of pristane, phytane, and generally $n$-alkane compounds. These compounds may have originated mostly from aquatic photosynthetic organisms. The oil shale was likely deposited in an anoxic lake environment as suggested by the presence of framboidal pyrite $(6 \%$, $\mathrm{v} / \mathrm{v}$ ) and preserved organic matter with a total organic carbon (TOC) percentage of about $4.9 \%$. The pristane/phytane ratio was relatively high (about 3.9) and thought to be source sensitive rather than redox sensitive. Hopanoid and aryl isoprenoid compounds were present in minor amounts. The latter compounds are interpreted to be derived from green sulfur bacteria dwelling in an anoxic environment with the presence of $\mathrm{H}_{2} \mathrm{~S}$ in bottom water.
\end{abstract}

Keywords: depositional environment; Ombilin Basin; organic geochemistry; organic petrology; Sangkarewang oil shale.

\section{$1 \quad$ Introduction}

Oil shales are defined as organic-rich shales containing significant amounts of oil-prone kerogen and liberating crude oil upon heating [1]. Some authors regard oil shales not only as shales but also as marls and carbonates with varying proportions of clay minerals, quartz and feldspars [2]. Oil shales consist of a diverse composition of organic matter, reflecting a wide range of sedimentary environments. The rock contains more than $5 \%$ of organic content and can be benefited as alternative source for fossil fuels by retorting [2].

Received February $25^{\text {th }}, 2014,1^{\text {st }}$ Revision September $16^{\text {th }}, 2014,2^{\text {nd }}$ Revision October $14^{\text {th }}, 2014$, Accepted for publication October $23^{\text {rd }}, 2014$.

Copyright (C) 2014 Published by ITB Journal Publisher, ISSN: 2337-5779, DOI: 10.5614/j.eng.technol.sci.2014.46.4.6 
In recent years, oil shales have been of interest in Indonesia as they are expected to greatly increase the oil resources [3]. Some drilling programs have been performed during the last decade to map geological features relating to the occurrence of oil shales in order to explore and make inventory of its resources throughout the Indonesian basins, among which the Ombilin Basin. Several studies have also been performed to assess the possibility of utilizing the oil shales.

The Sangkarewang Formation is known as a strata bearing lacustrine organicrich rock in the Ombilin Basin deposited during the Paleogene. Some studies have been carried out in order to investigate the geological framework and petroleum system [4-8]. However, these studies dealt only with general geological approaches such as geological mapping, petrography, palynology, and mineralogy. The organic geochemistry of Indonesian oil shales has never been reported in detail.

This study characterizes the organic matter composition of the Sangkarewang oil shale by means of organic petrology and geochemistry. Macerals and compounds that compose the organic matter of the oil shale will be identified and investigated with respect to their origin and paleoenvironment. The results were expected to provide improvement of the Sangkarewang depositional settings interpretation.

\section{Geological Settings}

The Ombilin Basin is a Tertiary intramontane basin located in the Barisan Mountains on Sumatra Island, Indonesia (Figure 1). It is a graben-like, pullapart structure resulting from early Tertiary tensional tectonics related to strikeslip movement along the Sumatra Fault Zone [5].

The Ombilin Basin is surrounded by permo-carboniferous slates, phyllites, marble, limestone (Kuantan Formation), and large intrusions of granitic rock to the north, east, and south. A complex assemblage of pre-Tertiary rocks is also exposed along the western margin of the basin [5]. The stratigraphy of the Ombilin Basin according to Koesoemadinata and Matasak [4] and de Smet and Barber [9] is shown in Figure 2. It can be described as follows:

a. The Brani Formation is a sequence of purple-brown coloured breccias and polymictic pebble to cobble conglomerates with a muddy to sandy matrix, very poorly sorted, generally non-bedded to occasionally poorly bedded, formed partly as alluvial fan and partly as coastal deposits.

b. The Sangkarewang Formation is composed of dark bluish grey to black fine laminated shales. The shales are typically plastic and papery and are locally 
calcareous but contain carbonaceous material with mica, pyrite, and plant remains. There are a few inter-bedded greenish-grey feldspathic turbidite sandstones with a thickness of less than $1 \mathrm{~m}$. The shales were deposited in a lacustrine environment.

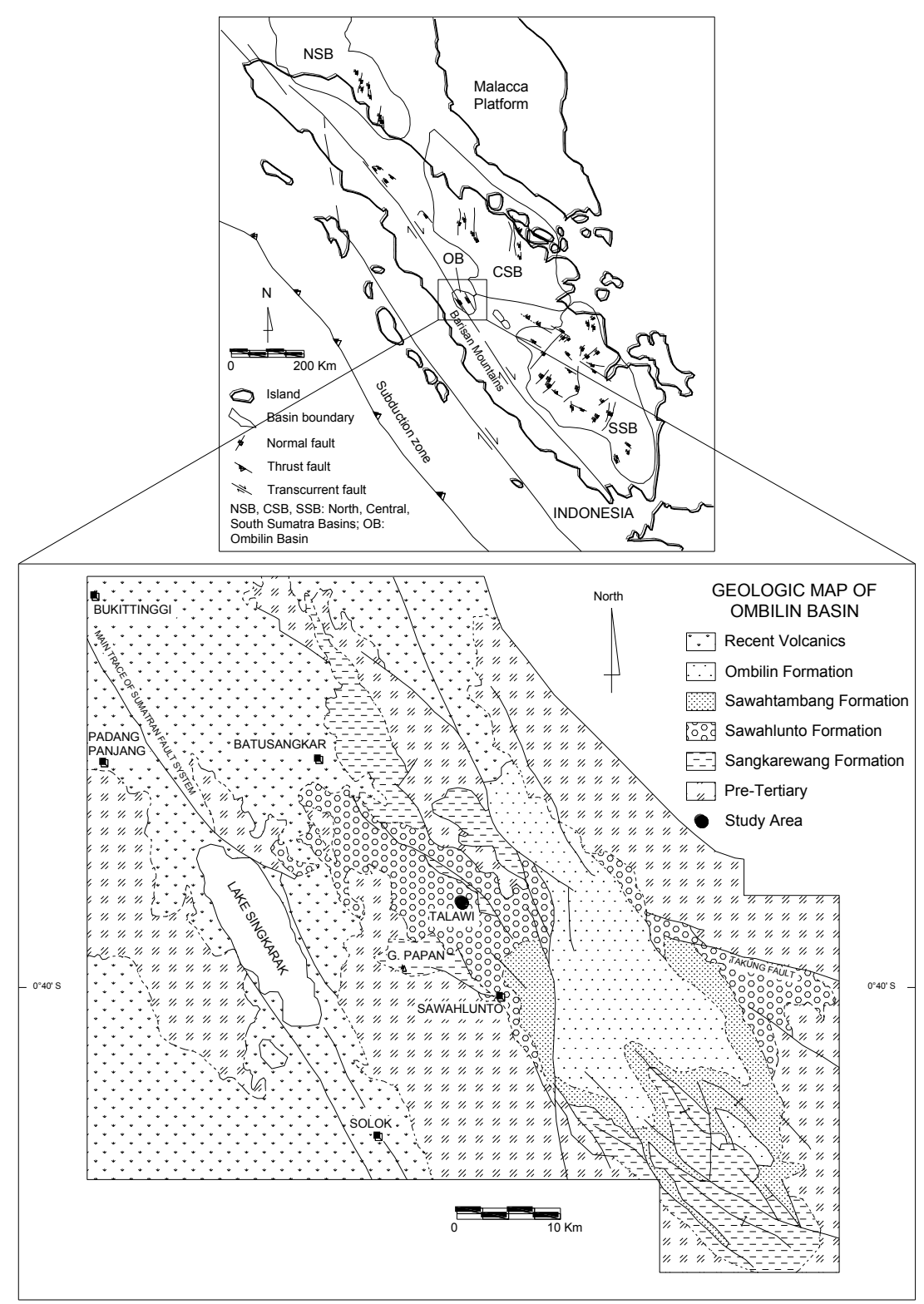

Figure 1 Ombilin Basin and tectonic settings of Sumatra (modified from Koesoemadinata and Matasak [4] and Koning [5]). 
c. The Sawahlunto Formation consists of a sequence of brownish shales, silty shales, and siltstones and inter-bedded brown, dense, quartz sandstones and is characterized by the presence of coal. The shales are usually carbonaceous or coaly and act as underclays. This formation is considered to be a flood basin and meandering river deposit.

d. The Sawahtambang Formation consists of a thick massive sequence of cross-bedded sandstones, mostly quartzose to feldspathic.

e. The Ombilin Formation is characterized by dark grey carbonaceous and calcareous shales.

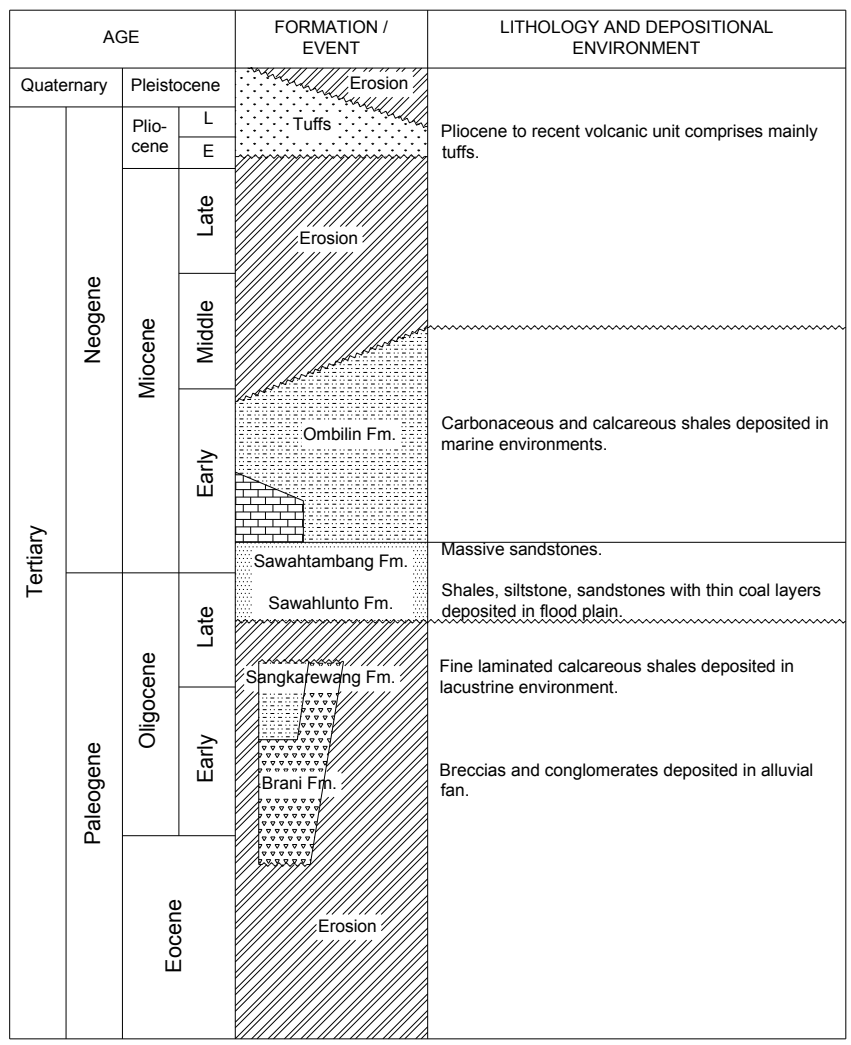

Figure 2 Stratigraphic column of the Ombilin Basin (modified from Koesoemadinata and Matasak [4] and de Smet and Barber [9]).

The study area is located in Talawi, where the Sangkarewang Formation is well exposed (Figure 1). The Sangkarewang Formation is well known due to the fossil finds of fresh water fish. It was deposited in a stable lacustrine environment with euxinic conditions, possibly a large lake covering at least 
$1000 \mathrm{~km}^{2}$. In petroleum geology, the Sangkarewang Formation is interesting as it consists of a massive and nearly mature oil shale [8].

\section{$3 \quad$ Materials and Methods}

\subsection{Materials}

Five samples were taken from a $56 \mathrm{~m}$ long WL-2 drill core recovered from the Sangkarewang Formation, which is available at the depository sample house of the Center of Geological Resources (PSDG), Bandung, Indonesia. Grab sampling was applied at five points distributed along the core, as shown in Figure 3 . The core consisted typically of fine-grained laminated oil shale with a hard papery structure, dark brown color, and plant remains found in some parts. Breccia and some thin layers of sandstone were present in some parts of the profile.

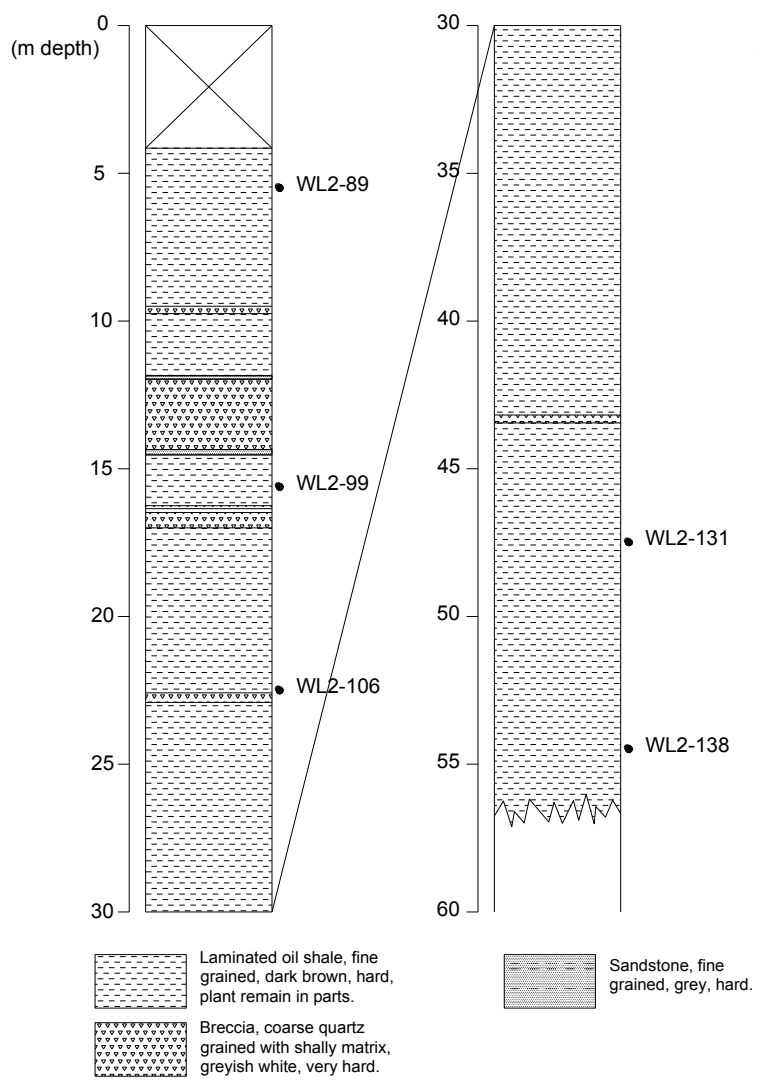

Figure 3 Profile of WL-2 drill core of Sangkarewang Formation and sampling points. 


\subsection{Methods}

\subsubsection{Petrographic Analysis}

Sample preparation and analysis procedures for the petrographic analysis followed those described by Taylor, et al. [10]. Oil shale particles of about 1 $\mathrm{mm}$ in size were prepared for polished sections. The particles were embedded in a silicon mould using epoxy resin as embedding medium. The samples were then ground and polished. Microscopic analysis was performed with a Zeiss Axio Imager A2m reflected-light microscope to identify and quantify macerals in the oil shale. At least 300 points were counted for macerals and minerals. The mean random vitrinite reflectance was measured on the surface of vitrinite particles under oil immersion on the microscope. About twenty-five points of vitrinite reflectance were measured on each sample. Maceral composition was analyzed in the Laboratory of Mining Exploration, Bandung Institute of Technology, while the reflectance measurement was conducted in the Laboratory of Physics, Center of Geological Resources, Bandung, Indonesia.

\subsubsection{Geochemical Analysis}

Total organic carbon contents (TOC) measurement was performed using a Euro EA (CAP 20) Elemental Analyzer. Before the analysis, pulverized samples with less than 200 micron grain size were treated with diluted (10\%) hydrochloric acid to remove carbonates and then rinsed with distilled water until neutrality. In view of calcite loss, the TOC values were corrected to the original sample weight.

Gas chromatography-mass spectrometry (GC-MS) measurement was carried out in order to investigate the organic compounds existing in the oil shale. Twentyfive grams of pulverized oil shale sample material $(<200$ micron) was extracted for 24 hours in a soxhlet extraction apparatus using $200 \mathrm{ml}$ dichloromethane (DCM) as solvent. The extract was analyzed using a Thermo Scientific Ultra series gas chromatograph coupled to a Thermo Scientific DSQ II mass spectrometer. GC separation of the compounds was achieved using a Thermo Scientific TR-5MS fused silica capillary column ( $30 \mathrm{~m} \times 0.25 \mathrm{~mm}$ ID $\times 0.25$ $\mu \mathrm{m}$ film thickness). The oven temperature was programmed from 60 to $320^{\circ} \mathrm{C}$ at a rate of $4{ }^{\circ} \mathrm{C} / \mathrm{min}$, with a $35 \mathrm{~min}$ isothermal period at $320^{\circ} \mathrm{C}$. The samples were injected in the splitless mode with the injector temperature at $280^{\circ} \mathrm{C}$. Helium was used as carrier gas. The mass spectrometer was operated in the electron impact mode (EI) at $70 \mathrm{eV}$ ionization energy. Mass spectra were obtained by scanning from 50 to 600 Daltons at a cycle time of 1 second. Perdeuteratedtetracosane was used as internal standard for quantification. GC-MS 
analysis was done in the Institute of Atmospheric and Environmental Sciences, Goethe University, Frankfurt am Main, Germany.

\section{$4 \quad$ Results}

\subsection{Petrographic Analysis}

The results of the petrographic analysis of the five samples show that the macerals composing the Ombilin oil shale are alginite, vitrinite, and resinite. Alginite is the most abundant maceral, accounting for about $30 \%(\mathrm{v} / \mathrm{v})$ of the oil shale (Table 1). It consists mostly of lamalginite, while telalginite is present only in a very limited amount. Lamalginite exhibits a lamellar structure that is interlayered by minerals. Photomicrographs of the macerals and minerals are shown in Figure 4.

Vitrinite and resinite are minor components, about $4 \%(\mathrm{v} / \mathrm{v})$ and less than $1 \%$ $(\mathrm{v} / \mathrm{v})$, respectively. Vitrinite is present as small grains, rarely dispersed in the samples. Dark coatings and holes are sometimes observed in the vitrinite debris. Vitrinite reflectance $(\mathrm{Rr})$ measurement values ranged from 0.43 to $0.51 \%$ with an average value of $0.46 \%$.

Minerals account for about $65 \%(\mathrm{v} / \mathrm{v})$ of the oil shale. The minerals consist mostly of calcite and clay minerals and commonly pyrite. Pyrite is present in a minor amount, averaging at $6 \%(\mathrm{v} / \mathrm{v})$. It mostly shows a framboidal structure.

Table 1 Results of the petrographic and geochemical analyses.

\begin{tabular}{lrl}
\hline \multicolumn{1}{c}{ Parameter } & $\begin{array}{c}\text { Average } \\
\text { Value }\end{array}$ & \multicolumn{1}{c}{ Unit } \\
\hline Alginite (mostly lamalginite) & 30 & $\%(\mathrm{v} / \mathrm{v})$ \\
Vitrinite & 4 & $\%(\mathrm{v} / \mathrm{v})$ \\
Resinite & $<1$ & $\%(\mathrm{v} / \mathrm{v})$ \\
Minerals (incl. pyrite) & 65 & $\%(\mathrm{v} / \mathrm{v})$ \\
Pyrite & 6 & $\%(\mathrm{v} / \mathrm{v})$ \\
Rr & 0.46 & $\%$ \\
Carbonates & 55 & $\%$ \\
TOC & 4.9 & $\%$ \\
Pristane & 991.7 & $\mu \mathrm{g} / \mathrm{g}$ TOC \\
Phytane & 266.5 & $\mu \mathrm{g} / \mathrm{g}$ TOC \\
Pristane/Phytane & 3.9 & \\
$\mathrm{C}_{17}$-alkane & 635.2 & $\mu \mathrm{g} / \mathrm{g}$ TOC \\
$\mathrm{C}_{27}$-alkane & 403.6 & $\mu \mathrm{g} / \mathrm{g}$ TOC \\
CPI & 1.2 & \\
\hline
\end{tabular}




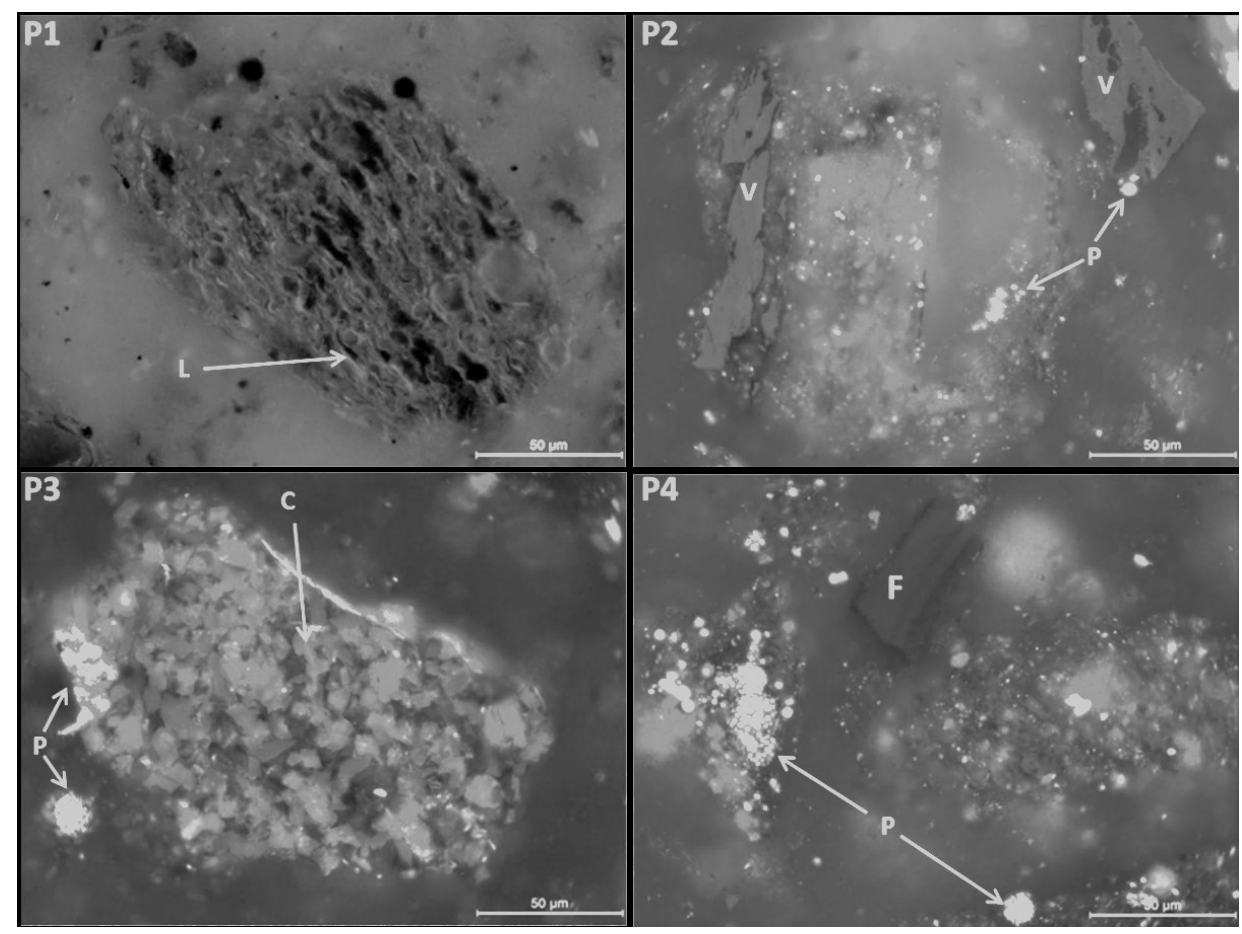

Figure 4 Photomicrographs of the Sangkarewang oil shale in oil immersion: lamalginite (L) shows a lamellar structure, vitrinite (V) present as small grains, pyrite $(\mathrm{P})$ typically exhibiting framboidal structure, calcite $(\mathrm{C})$ found throughout the polished sections, and fish remains $(F)$ sometimes observed in the samples. The scale bars indicate $50 \mu \mathrm{m}$ of length. P1 was taken under fluorescence illumination.

Table 2 Peak assignment of compounds shown in Figure 5.

\begin{tabular}{llcc}
\hline Peak & Compound & Base Peak & Mass Weight \\
\hline $\mathrm{Pr}$ & Pristane & 57 & 268 \\
$\mathrm{Ph}$ & Phytane & 57 & 282 \\
$\mathrm{Std}$ & Internal standard & & \\
1 & $\mathrm{C}_{13}$ Aryl isoprenoid & 133 & 176 \\
2 & $\mathrm{C}_{14}$ Aryl isoprenoid & 133 & 190 \\
$\mathrm{a}$ & $17 \alpha(\mathrm{H})-22,29,30$-Trisnorhopane & 191 & 370 \\
$\mathrm{~b}$ & $17 \beta(\mathrm{H})-22,29,30$-Trisnorhopane & 149 & 370 \\
$\mathrm{c}$ & $17 \alpha(\mathrm{H}), 21 \beta(\mathrm{H})-30-$ Norhopane & 191 & 398 \\
$\mathrm{~d}$ & $17 \alpha(\mathrm{H}), 21 \beta(\mathrm{H})-$ Hopane & 191 & 410 \\
$\mathrm{e}$ & $22 \mathrm{R}-17 \alpha(\mathrm{H}), 21 \beta(\mathrm{H})$-Homohopane & 191 & 426 \\
\hline
\end{tabular}




\subsection{Geochemical Analysis}

The total organic carbon (TOC) contents of the raw samples are $4.9 \%$ on average (Table 1). The values are relatively low as compared to the organic carbon content of common economic oil shales $(>10 \%)$ [9]. The carbonate contents measured as weight loss after acid treatment are very high, averaging at $55 \%$ of the raw samples. This analysis result suggests that the samples being studied represent a calcareous shale of the Sangkarewang Formation.

The chromatogram of a representative sample total organic extract is shown in Figure 5. The $n$-alkane compounds, marked by dots in the figure, are dominant in all samples. Pristane is the most abundant compound in all samples (averaging at $991.7 \mu \mathrm{g} / \mathrm{g}$ TOC), whereas phytane is much lower than pristane (averaging at $266.5 \mu \mathrm{g} / \mathrm{g}$ TOC). The pristane/phytane $(\mathrm{Pr} / \mathrm{Ph})$ ratio averages at 3.9. Mass fragmentograms for $\mathrm{m} / \mathrm{z} 133$ and $\mathrm{m} / \mathrm{z} 191$ of the total extract are also shown in Figure 5, indicating the presence of aryl isoprenoids and hopanoids, respectively. Peak assignment for the compounds is listed in Table 2.

The $n$-alkanes in the samples range from $\mathrm{C}_{14}$ to $\mathrm{C}_{35}$, showing odd over even predominance in all samples (Figure 5). The compounds exhibit bimodal distribution, peaking at $\mathrm{C}_{17}$ and $\mathrm{C}_{27}$. The $\mathrm{C}_{27}$ is the most abundant compound of the $n$-alkanes, averaging at $635.2 \mu \mathrm{g} / \mathrm{g}$ TOC. Of the short-chain $n$-alkanes, $\mathrm{C}_{17}$ is the most abundant, with an average value of $403.6 \mu \mathrm{g} / \mathrm{g}$ TOC. The carbon preference index (CPI) based on Bray and Evans [11] was calculated for $\mathrm{C}_{24}-\mathrm{C}_{33}$ $n$-alkanes. The CPI values are similar for the five samples; the values range from 1.13 to 1.36 , averaging at 1.21 . The higher CPI values (more than 1.0) reflect an odd over even predominance of the long-chain $n$-alkanes.

The presence of $\mathrm{C}_{13}$ and $\mathrm{C}_{14}$ aryl isoprenoids (compounds 1 and 2) is indicative of a depositional environment. The identification of these compounds refers to the mass spectra published by Requejo, et al. [12]. Aryl isoprenoids occur only in trace amounts; the peaks were identified from mass fragmentogram of $\mathrm{m} / \mathrm{z}$ 133 (Figure 5).

Hopanoid homologues also occur in very low amounts. Some of $\mathrm{C}_{27}, \mathrm{C}_{29}, \mathrm{C}_{30}$, and $\mathrm{C}_{31}$ hopanoid peaks could be identified in the mass fragmentogram of $\mathrm{m} / \mathrm{z}$ 191 (Figure 5). Other compounds in the hopanoid homologues may be present in very limited amounts but could not be observed. 


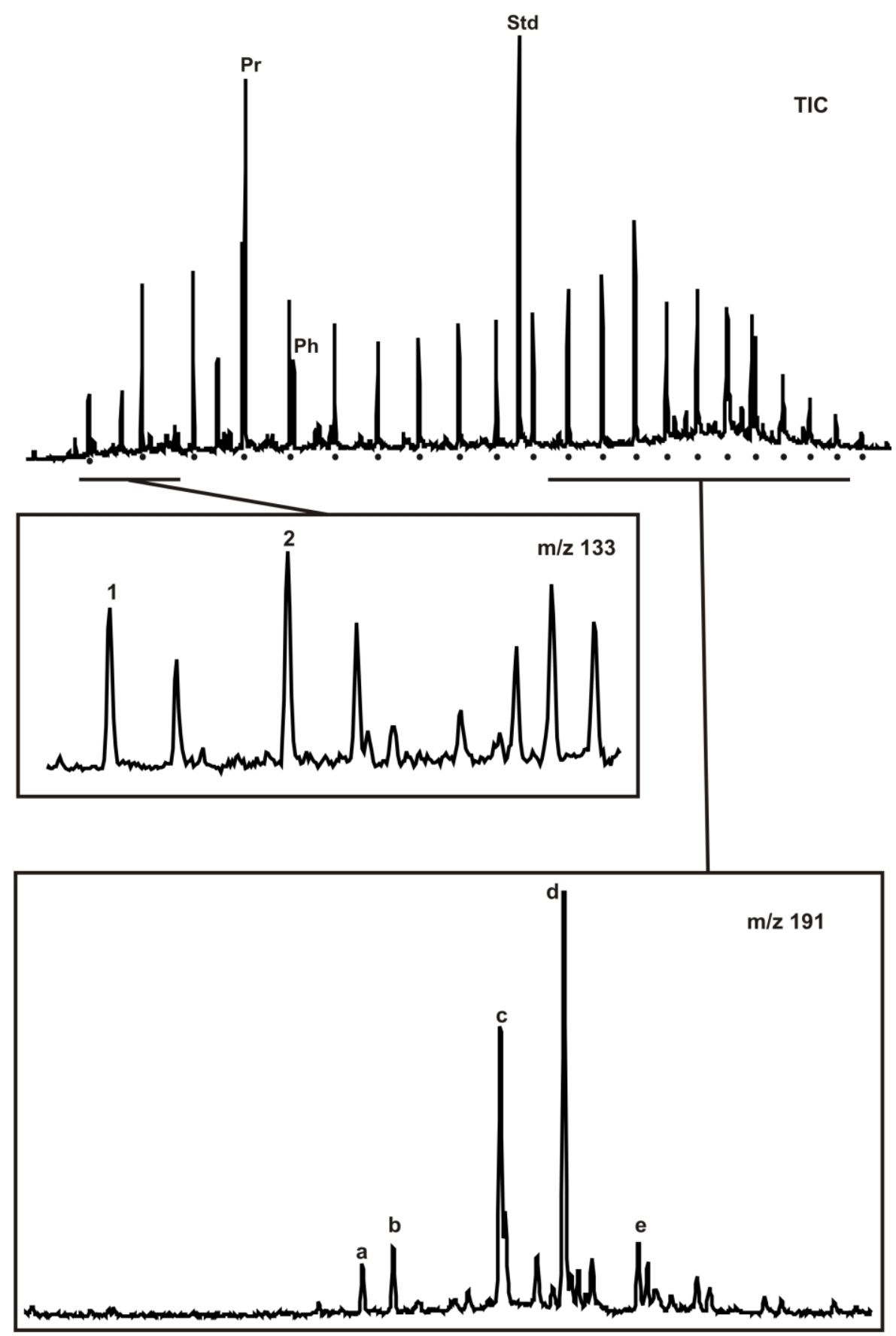

Figure 5 Mass chromatogram of total extract of representative sample (WL089) for total ion (TIC), m/z 133, and m/z 191. Dots denote n-alkane peaks. 


\section{Discussion}

\subsection{Organic Matter Origin}

According to the petrographic analyses, the organic matter is mostly composed of lamalginite. Macerals are commonly derived from microalgae with thin cellular wall and bacteria [13]. The organisms, due to a weak or absent cellular wall, most probably decayed easily during deposition and diagenesis. This results in the absence of a clear structure and morphology of the lamalginite maceral. Vitrinite and resinite are two recognized components which originate from higher plants.

Organic geochemical analyses reveal the predominance of $n$-alkanes in the total extract of the Ombilin oil shale. $n$-Alkanes in oil shale are commonly derived from various sources. Short-chain $n$-alkanes $\left(\mathrm{C}_{15}-\mathrm{C}_{19}\right)$ showing odd over even predominance are typically derived from algae and photosynthetic bacteria $[14,15]$. Long-chain $n$-alkanes $\left(>C_{24}\right)$ commonly originate from epicuticular waxy coatings of vascular plants and some green and blue-green algae [14-17]. In the present case, the short-chain $n$-alkanes most likely were derived from algae and/or photosynthetic bacteria, while the long-chain $n$-alkanes may have been generated by green and/or blue green algae. In the latter, vascular plants are less significant due to less contribution of terrestrial sources, as evidenced by the limited amounts of terrestrial-derived macerals.

Pristane and phytane are ubiquitous in sediments. These compounds have various biological sources. The common origin of pristane and phytane are phytyl side chains of chlorophyll a in photosynthetic organisms and bacteriochlorophyll $\mathrm{a}$ and $\mathrm{b}$ in purple sulfur bacteria $[15,18]$. In the Ombilin oil shale it is unlikely that pristane and phytane were generated from photosynthetic higher plants, as vitrinite maceral in the organic matter is very limited. Algae and photosynthetic bacteria are proposed as the organisms most responsible for the occurrence of pristane and phytane.

Algae with thick cellular walls are unlikely as the main precursors of Ombilin oil shale organic matter, because such organisms will derive structured alginite or telalginite maceral. In the Ombilin oil shale, telalginite occurs only in very limited amounts. Microalgae and bacteria are thus suggested as the principal biological precursors of the lamalginite maceral as well as the $n$-alkane compounds, pristane, and phytane. Additionally, the presence of hopanoid compounds support the explanation that bacteria were an important source of the organic matter. Although the compounds occur only in low abundance, it is likely that most of the compounds have been converted into $n$-alkanes during 
late diagenesis. The vitrinite reflectance is about $0.46 \%$, indicating nearly mature organic matter.

Aryl isoprenoids are cleavage products of isorenieratene. In the Ombilin oil shale, the carotenoids could not be recognized in the GC-MS analysis. It is probable that all carotenoids have been mostly converted to other compounds, including aryl isoprenoids, during late diagenesis. Carotenoids in oil shale may originate from some biological sources, including algae, carotenogenic actinobacteria and green sulfur bacteria [19,20,21]. All these organisms can dwell in a freshwater environment, so they may partly be responsible for the presence of aryl isoprenoids in Ombilin oil shale.

\subsection{Depositional Environment}

The predominance of lamalginite in the organic matter and the very limited amount of higher plant macerals, such as vitrinite and resinite, strictly indicate aquatic depositional settings for the Ombilin oil shale. The vitrinite is thought to originate from terrestrial higher plants sources, not from aquatic higher plants, by the presence of dark coatings and holes, which represent weathering parts during material transportation. The deposition environment may be relatively deep, as the vitrinite has been transported longer and present in limited amounts.

Deep depositional environments promoted the establishment of anoxic bottom water of many ancient lakes [1,22], including most likely Ombilin lake. The existence of anoxic bottom water during deposition of the Sangkarewang oil shale is evidenced by the occurrence of framboidal pyrite observed in the petrographic analysis. Framboidal pyrite is only derived in anoxic environments, as the agent bacteria require such conditions [23]. Koesoemadinata and Matasak [4] also reported that the Sangkarewang Formation was deposited in a deep anoxic-euxinic environment.

Anoxic bottom water provides good conditions for preservation of organic matter, as anaerobic degradation is thermodynamically less efficient than aerobic degradation [1]. Deep anoxic environments in the former Ombilin lake may have been responsible for the preservation of organic matter in the Sangkarewang oil shale.

The pristane/phytane ratio $(\mathrm{Pr} / \mathrm{Ph})$ is commonly used to infer anoxicity of depositional environment [15]. Anoxic environments lead to reduction of phytyl side chains to phytol and then to phytane, so that the $\mathrm{Pr} / \mathrm{Ph}$ will be low. On the other hand, oxic environments lead to oxidation of phytol to pristane, so the $\mathrm{Pr} / \mathrm{Ph}$ will be high. In the Ombilin oil shale, the $\mathrm{Pr} / \mathrm{Ph}$ is relatively high (about 3.9), suggesting an oxic depositional environment. The high $\mathrm{Pr} / \mathrm{Ph}$ is in contrast 
with the presence of framboidal pyrite, which is only deposited in strictly anoxic depositional environments.

Pristane and phytane could also be derived other than from phytyl side chains of chlorophyl a. These compounds could have been generated from archaebacterial membrane lipids [24]. Additionally, pristane may also originate from tocopherols [25] and methyltrimethyltridecylchromans (MTTC) [26]. Considering the various sources of pristane and phytane, Rontani, et al. [27] have suggested that $\mathrm{Pr} / \mathrm{Ph}$ as redox indicator should be applied with care, because the results are not always reliable. Hence, it is proposed that the high $\mathrm{Pr} / \mathrm{Ph}$ in the Ombilin oil shale is source dependent rather than redox sensitive.

The occurrence of aryl isoprenoids is interesting. The carotenoid derivatives may be indicative for the presence of green sulfur bacteria as the biological source [19]. Green sulfur bacteria require sulfur $\left(\mathrm{H}_{2} \mathrm{~S}\right)$ and light for photosynthesis. In aquatic systems, the presence of $\mathrm{H}_{2} \mathrm{~S}$ is restricted only to anoxic bottom water. Hence, the aryl isoprenoids in the Ombilin oil shale may indicate bottom water with no oxygen (anoxic), an abundance of sulfur, and light being able to penetrate into this zone. This confirms the interpretation reported by Koeseomadinata and Matasak [4] that the Sangkarewang Formation was deposited under euxinic conditions.

\section{Conclusions}

The organic matter of the Ombilin oil shale is composed mostly from lamalginite with minor amounts of vitrinite and resinite. The hydrocarbon compounds identified in the oil shale are dominated by $n$-alkanes, pristane, and phytane. Hopanoid compounds and aryl isoprenoids were recognized in trace amounts. The organic matter may have been derived mostly from microalgae and bacteria, including green sulfur bacteria, which indicates a euxinic depositional environment.

\section{Acknowledgements}

We are most grateful for the financial support partly provided by LPPM-ITB through "Research of Capacity Enhancement 2012". Technical assistance from R. Kusprasetianty and I. Khoiri with the petrographical analysis is gratefully acknowledged. 


\section{References}

[1] Peters, K.E., Walters, C.C. \& Moldowan, J.M., The Biomarker Guide Vol. 1: Biomarkers and Isotopes in the Environment and Human History, $2^{\text {nd }}$ ed., Cambridge University Press, New York, 2005.

[2] Tissot B.P. \& Welte D.H., Petroleum Formation and Occurrence, Springer-Verlag, New York, 1984.

[3] DJMIGAS, Energy Development in Indonesia: Opportunities and Challenge, Presentation of Direktorat Jenderal Minyak dan Gas Bumi (DJMIGAS), Indonesian Ministry of Energy and Mineral Resources in Rotes Rathaus, Berlin, October 13, 2010.

[4] Koesoemadinata, R.P. \& Matasak, T., Stratigraphy and sedimentation of Ombilin Basin, Central Sumatra (West Sumatra Province), Proceedings Indonesian Petroleum Association $10^{\text {th }}$ Annual Convention, Jakarta, pp. 217-249, 1981.

[5] Koning, T., Petroleum geology of the Ombilin Intermontane Basin, West Sumatra, Proceedings Indonesian Petroleum Association $14^{\text {th }}$ Annual Convention, Jakarta, pp. 117-137, 1985.

[6] Situmorang, B., Yulihanto, B., Guntur, A., Himawan, R. \& Jacob, T.G., Structural Development of The Ombilin Basin, West Sumatra, Proceedings Indonesian Petroleum Association $20^{\text {th }}$ Annual Convention, Jakarta, IPA 91-11.01, 1991.

[7] Fatimah \& Ward, C., Mineralogy and Organic Petrology of Oil Shales in the Sangkarewang Formation, Ombilin Basin, West Sumatra, Indonesia, International Journal of Coal Geology, 77, pp. 424-435, 2009.

[8] Widayat, A.H., Anggayana, K., Syafrizal, Heriawan, M.N., Hede, A.N.H. \& Hakim, A.Y.A., Organic matter characteristics of the Kiliran and Ombilin oil shales, Indonesia, Procedia Earth and Planetary Science, 6, pp. 91-96, 2013.

[9] De Smet, M.E.M. \& Barber, A.J., Chapter 7: Tertiary Stratigraphy. Sumatra, Geological Society Memoirs, 31, pp. 86-97, 2005.

[10] Taylor, G.H., Teichmüller, M., Davis, A., Diessel, C.F.K., Littke, R. \& Robert, P., Organic Petrology, Gebrüder Borntraeger, Berlin, 1998.

[11] Bray, E.E. \& Evans, E.D., Distribution of n-Paraffins as A Clue to Recognition Of Source Beds, Geochimica et Cosmochimica Acta, 22, pp. 2-15, 1961.

[12] Requejo, A. G., Allan, J., Creaney, S., Gray, N. R. \& Cole, K. S., Aryl Isoprenoids and Diaromatic Carotenoids in Paleozoic Source Rocks and oils from the Western Canada and Williston Basins, Organic Geochemistry, 19, pp. 245-264, 1992.

[13] Hutton, A.C., Petrographic Classification Of Oil shales, International Journal of Coal Geology, 8, pp. 203-231, 1987. 
[14] Moldowan, J.M., Seifert, W.K. \& Gallegos, E.J., Relationship between Petroleum Composition and Depositional Environment of Petroleum Source Rocks, AAPG Bulletin, 69, pp. 1255-1268, 1985.

[15] Peters, K.E., Walters, C.C. \& Moldowan, J.M., The Biomarker Guide Vol. 2: Biomarkers and Isotopes in Petroleum Exploration and Earth History, $2^{\text {nd }}$ ed., Cambridge University Press, New York, 2005.

[16] Eglinton, G. \& Hamilton, R.J., Leaf Epicuticular Waxes, Science, 156, pp. 1322-1335, 1967.

[17] Gelpi, E., Schneider, H., Mann, J. \& Oró, J., Hydrocarbons of Geochemical Significance in Microscopic Algae, Phytochemistry, 9, pp. 603-612, 1970.

[18] Powell, T.G. \& McKirdy, D.M., Relationship between Ratio of Pristane to Phytane, Crude Oil Composition and Geological Environment in Australia, Nature Physical Science, 243, pp. 37-39, 1973.

[19] Koopmans, M.P., Schouten, S., Kohnen, M.E.L. \& Sinninghe Damsté, J.S., Restricted Utility of Aryl Isoprenoids as Indicators for Photic Zone Anoxicity, Geochimica et Cosmochimica Acta, 60, pp. 4873-4876, 1996.

[20] Krügel, H., Krubasik, P., Weber, K., Saluz, H.P. \& Sandmann, G., Functional Analysis of Genes from Streptomyces Griseus Involved in The Synthesis of Isorenieratene, A Carotenoid with Aromatic End Groups, Revealed A Novel Type of Carotenoid Desaturase, Biochimica et Biophysica Acta, 1439, pp. 57-64, 1999.

[21] Maresca, J.A., Romberger, S.P. \& Bryant, D.A., Isorenieratene Biosynthesis in Green Sulfur Bacteria Requires The Cooperative Actions of Two Carotenoid Cyclases, Journal of Bacteriology, 190, pp. 63846391, 2008.

[22] Demaison, G.J. \& Moore, G.T., Anoxic Environments and Oil Source Bed Genesis, Organic Geochemistry, 2, pp. 9-31, 1980.

[23] Chowdhury, A.H. \& Noble, J.P.A., Organic Carbon and Pyrite Sulphur Relationships As Evidences of Bottom Water Conditions of Sedimentation, Albert Formation Fine-Grained Lacustrine Sediments, New Brunswick, Canada, Marine and Petroleum Geology, 13, pp. 79-90, 1996.

[24] Chappe, B., Albrecht, P. \& Michaelis, W., Polar Lipids of Archaebacteria in Sediments and Petroleums, Science, 217, pp. 65-66, 1982.

[25] Goossens, H., de Leeuw, J.W., Schenck, P.A. \& Brassell, S.C., Tocopherols as Likely Precursors of Pristane in Ancient Sediments and Crude Oils, Nature, 312, pp. 440-442, 1984.

[26] Li, M., Larter, S.R., Taylor, P., Jones, D.M., Bowler, B. \& Bjoroy, M., Biomarkers or Not Biomarkers? A New Hypothesis For The Origin of Pristane Involving Derivation from Methyltrimethyltridecylchromans 
(Mttcs) Formed During Diagenesis from Chlorophyll and Alkylphenols, Organic Geochemistry, 23, pp. 159-167, 1995.

[27] Rontani, J.F., Nassiry, M., Michotey, V., Guasco, S. \& Bonin, P., Formation of Pristane from A-Tocopherol under Simulated Anoxic Sedimentary Conditions: A Combination of Biotic and Abiotic Degradative Processes, Geochimica et Cosmochimica Acta, 74, pp. 252263, 2010. 